D: $\mid$ Nsurg $\backslash$ Vol. 24, No. 3, Jul. - Sep., 2020\Nsurg-13.Doc

(A)

P. $277-282$

II

ORIGINAL ARTICLE

\title{
Pattern of Presentation of Spinal Dysraphism: A Study of 72 Patients in Hayatabad Medical Complex Peshawar, Pakistan
}

\author{
SOHAIL AMIR, MUHAMMAD NAWAZ KHAN, IMRAN KHAN \\ AYAZ AFRIDI, ATIF AMAN, MUSHTAQ, SHAHID AYUB \\ Department of Neurosurgery, Hayatabad Medical Complex, Medical Teaching Institute (MTI), \\ Peshawar-Pakistan
}

DOI: $10.36552 /$ pjns.v24i3.433

\section{ABSTRACT}

Objective: To review the pattern of presentation and current understanding of patients with spinal dysraphism in our local population.

Material and Methods: Cases of spinal dysraphism of any gender and age were admitted via OPD, emergency or referred from another department were included in the study. Information on demographics, developmental history, presenting symptoms, presence/absence of back swelling, hairy patches, a nevus, dimple, an appendage/ skin tag, lower limb function, sensory/ motor deficit, bowel and bladder dysfunction were recorded. MRI spine was done in all patients to know the exact diagnosis.

Results: Out of 72 cases, 52 (72.2\%) presented with spina bifida Aperta (spina bifida cystica) while 20 (27.7\%) with spina bifida occulta. Total 53 (73.6\%) patients presented at the age of $0-1$ years. 41 (56.9\%) of the patient presented with visible sac, 35 (48.6\%) swelling over the back, in 5 (6.9\%) of patient have hairy patch and dermal sinus each, while 28 (38.8\%) patients have neurological deficit. Most common type of spinal dysraphism was myelomeningocele $45(62.5 \%)$. Postoperative course of patients with spinal dysraphism was found to be uneventful in $56(77.7 \%)$, wound infection was seen in 11 (15.2\%), deterioration of neurological status in 3 (4.16\%) of cases.

Conclusion: Spinal dysraphism is not an uncommon condition in our local population its clinical presentation and features are in line with internationally reported literature. Our population is least aware of the adverse neurological outcomes of the condition and face difficulties to access the adequate healthcare for spinal dysraphism.

Keywords: Spina bifida, myelomeningocele, spinal dysraphism.

Abbreviations: SCM: Split Cord Malformation. HCP: Hydrocephalus. ACM: Arnold Chiari Malformation. TCS: Tethered Cord Syndrome. CT: Computed Tomography. CSF: Cerebrospinal Fluid. MRI: Magnetic Resonance Imaging.

\section{INTRODUCTION}

Spinal dysraphism is a group of congenital deformities of the spine in which the dorsal midline structure fails to fuse in normal fashion. It can be broadly classified in to spina bifida aperta (open type also named spina bifida aperta) in which overlying skin is not intact causing leakage of cerebrospinal fluid. The examples are myelomeningocele, myeloschisis. The second type is Spina bifida occulta (close type) in which the defect is fully covered with skin and the examples are meningocele, lipomyelomeningocele, split cord malformation and congenital dermal sinus..$^{1-3}$ The incidence of spinal dysraphism is 1-3/1000 live births. ${ }^{4}$

In spinal dysraphism, the primary embryological 
defect is due to failure of, or incomplete closure of neural tube. This process normally occurs during third to fourth week of intrauterine life. The exact etiology is not known, however genetic, nutritional and environmental factors are involved in the development of this anomaly. ${ }^{5,6}$

Spinal dysraphism patients present with swelling in the back region which is often noticed at birth. The skin over the swelling may be ruptured during labour resulting in cerebrospinal fluid leak, contamination and meningitis. ${ }^{7}$ In Spina bifida occulta (close type), one can see hairy patches, dimples, a nevus, an appendage or skin tag. Some older children may present with sensory motor and sphincter dysfunction depending upon the severity and level of anomaly ${ }^{8}$. Defect predominantly involves the thoracolumbar, lumbosacral, lumbar, thoracic, cervical areas in decreasing order of frequency. The associated anomalies are hydrocephalus, chiari malformation, skeletal abnormalities such as kyphosis, scoliosis and deformity of long bone and feet. ${ }^{9,10}$

A meticulous examination of the nervous system is mandatory to diagnose the case of spinal dysraphism. Initially a radiological assessment should be done keeping in view the clinical condition. Plain $\mathrm{x}$-ray reveals the skull defect, spine deformity and bony anomalies. ${ }^{11}$ Ultrasonography is done for assessment of hydrocephalus. MRI is the gold standard radiological modality to study the neural tissue anomalies and to ascertain the degree of chiari malformation and hydrocephalus ${ }^{12}$.

The management of patients with spinal dysraphism is mostly surgical and often need multidisciplinary approach. The mortality rate has been found to be $35-45 \%$ in first year and $50-60 \%$ in first $3-5$ years. ${ }^{13}$ Parents should be counselled regarding the prognosis and different treatment strategies.

We live in under developed part of the world where nutritional status of potential mothers is not up to the mark hence hypothetically higher risk of spinal dysraphism. There is little literature available on patterns of spinal dysraphism in our local population. This study is primarily designed to elaborate the various patterns of this problem in our population and relative sub-share of each secondary-type of spinal dysraphism which will help the health authorities to plan community sensitization and awareness programs. Spina bifida occulta go unnoticed in our community until late growing ages and patients develop permanent neurologic deficit. It is our opinion that community awareness based on burden of disease of its various presentations may help masses seek timely medical help.

\section{MATERIAL AND METHODS}

\section{Study Design \& Setting}

This descriptive cross-sectional study was done in Neurosurgery department, Hayatabad Medical Complex, Peshawar from February 2018 to March 2020.

\section{Inclusion Criteria}

Cases of spinal dysraphism of any gender and age range from $0-18$ years were admitted via outpatient department, emergency or referred from pediatric/ Obstetric department were included in the study.

\section{Data Collection}

The data was collected on predesigned proforma. Informed, written consent was taken from parents of all children regarding their inclusion in the study. The institute ethical committee for research evaluation was approached for approval of the proposed study.

A total of 72 patients were recruited in this study. Data was collected about demographics, developmental history, presenting symptoms, duration of symptoms, birth history and maternal history.

\section{Clinical Examination}

A detailed clinical examination were performed and findings recorded like presence/absence of back swelling, hairy patches, a nevus, dimple, an appendage / skin tag, lower limb function, sensory deficit, motor deficit, bowel and bladder dysfunction, size and shape of head, skeletal abnormality like kyphosis, scoliosis and deformity of long bone and feet were also recorded.

MRI spine was done in all patients to know the exact diagnosis. CT scan spine was done in selected patient to detect possible associated anomaly like, split cord malformation (SCM), Hydrocephalus (HCP), Arnold Chiari Malformation (ACM), and tethered cord syndrome (TCS). Radiological finding were recorded for diagnosis and the level of dysraphism. Postoperatively, the patients were followed up to three months. 


\section{Data Analysis}

Immediate complications were recorded. SPSS 20.0 was used for the analysis of data and presented in tabular form.

\section{RESULTS}

\section{Background Information}

The sample size was 72 , all these cases were diagnosed with spinal dysraphism from February 2018 to March 2020. Out of 72 patients 52 (72.2\%) presented with spina bifida aperta, while $20(27.7 \%)$ with spina bifida occulta.

\section{Age Incidence}

A total of $53(73.6 \%)$ patients presented at the age of $0-1$ years, $9(12.5 \%)$ between $2-6$ years, $5(6.9 \%)$ between $6-12$ years and $5(6.9 \%) 13-18$ years of age.

\section{Gender Distribution}

Male were $48(66.6 \%)$ and female $24(33.3 \%)$ with male to female ratio was $2: 1$.

Table 1: Age Wise Distribution $(n=72)$.

\begin{tabular}{|l|c|c|c|}
\hline Age & $\begin{array}{c}\text { Spina Bifida } \\
\text { Aperta }\end{array}$ & $\begin{array}{c}\text { Spina Bifida } \\
\text { Occulta }\end{array}$ & Percentage \\
\hline$<24$ Hrs & 8 & 2 & $13.88 \%$ \\
\hline $\begin{array}{l}\text { 2 Days to 1 } \\
\text { Month }\end{array}$ & 18 & 5 & $31.9 \%$ \\
\hline $\begin{array}{l}\text { 2 Months to } \\
\text { 01 Year }\end{array}$ & 15 & 5 & $27.7 \%$ \\
\hline $\begin{array}{l}\text { 2 Years to 6 } \\
\text { Years }\end{array}$ & 5 & 4 & $12.5 \%$ \\
\hline $\begin{array}{l}\text { 6 Years to 12 } \\
\text { Years }\end{array}$ & 3 & 2 & $6.94 \%$ \\
\hline $\begin{array}{l}\text { 13 Years to } \\
18 \text { Years }\end{array}$ & 3 & 2 & $6.94 \%$ \\
\hline
\end{tabular}

\section{Clinical Presentation}

$41(56.9 \%)$ of the patients presented with visible sac, $35(48.6 \%)$ with swelling over the back, in $5(6.9 \%)$ of patient we observed a hairy patch and dermal sinus each while $28(38.8 \%)$ patient had neurological deficit. Out of 28 patients, $16(57.14 \%)$ were having paraplegia $12(42.8 \%)$ having grade 2 or less paraparesis while $15(53.7 \%)$ presented with a combination of both lower limb weakness and bowel/ bladder dysfunction.

In our study the most common type of spinal dysraphism was myelomeningocele 45 (62.5\%), followed by lipomyelomeningocele 12 (16.6\%), dermal sinus 4 (5.5\%), Klippel - Feil syndrome or blocked vertebrae $2(2.7 \%)$, tethered cord syndrome 6 $(8.3 \%)$ and split cord malformation seen in $3(4.16 \%)$. Myelomeningocele was mostly associated with hydrocephalus either before or after surgical repair which later need a CSF diversion procedure

In our study, the most common site was lumbosacral 20 (27.7\%), followed by dorsolumbar 18 (25\%), followed by lumbar $15(20.83 \%)$ area. Only 3 (4.16\%) had cervical meningocele.

Postoperative course of patients with spinal dysraphism was found to be uneventful in 56 (77.7\%), wound infection was seen in $11(15.2 \%)$, deterioration of neurological status in $3(4.16 \%)$ and re exploration was done in $2(2.77 \%)$ of cases.

Table 2: Modes of Clinical Presentation $(n=72)$.

\begin{tabular}{|l|c|}
\hline Clinical Presentation & No. of Patients \\
\hline Visible sac & 41 \\
\hline Swelling over back & 35 \\
\hline Dermal sinus & 5 \\
\hline Hairy patch & 5 \\
\hline Neurodeficit & 28 \\
\hline
\end{tabular}

Note: patient may present with one or more than one clinical presentation.

Table 3: Distribution of Cases Based on Type of Spinal Dysraphism $(n=72)$.

\begin{tabular}{|l|c|c|}
\hline Type & $\begin{array}{c}\text { No. of } \\
\text { Patients }\end{array}$ & Percentage \\
\hline Myelomeningocele & 45 & $62.5 \%$ \\
\hline Lipomyelomeningocele & 12 & $16.6 \%$ \\
\hline Dermal sinus & 4 & $5.5 \%$ \\
\hline Klippel - Feil Syndrome & 2 & $2.7 \%$ \\
\hline Tethered Cord Syndrome & 6 & $8.3 \%$ \\
\hline Split Cord Malformation & 3 & $4.16 \%$ \\
\hline
\end{tabular}


Table 4: Site of Spinal Dysraphism $(n=72)$.

\begin{tabular}{|l|c|c|}
\hline Site & No. of Patients & Percentage \\
\hline Cervical & 3 & $4.16 \%$ \\
\hline dorsal & 11 & $15.27 \%$ \\
\hline Lumbar & 15 & $20.83 \%$ \\
\hline Dorsolumbar & 18 & $25 \%$ \\
\hline Lumbosacral & 20 & $27.7 \%$ \\
\hline Sacral & 5 & $9.72 \%$ \\
\hline
\end{tabular}

\section{DISCUSSION}

The estimated incidence of spinal dysraphism worldwide is about 1-3/1000 live births. It seems that the prevalence rate has dropped all over the world due to the better antenatal care, folic acid supplementation and good nutrition for women. ${ }^{10}$ During $3^{\text {rd }}$ to $4^{\text {th }}$ week of fetal life the primary neural tube fail to close leading to spinal dysraphism, which is broadly classified in to spina bifida Aperta (open type) in which overlying skin is not intact and spina bifida occulta (close type) in which the overlying skin is intact but the spinal cord is anchored to various tissue like skin, subcutaneous tissue, adipose tissue or cartilage. ${ }^{14}$

In our study the most common age at presentation was $0-1$ year in $53(73 \%)$ of patients. A similar study was done by Mahapattra and Meneze and showed that $70 \%$ and $76 \%$ patients respectively, were presented in pediatric age group. ${ }^{15}$ We observed a male predominance $48(66 \%)$, which coincide with a study done by Raj and Singh in Northern India. ${ }^{16}$

In our study, $41(56.9 \%)$ of the patient presented with visible sac, $35(48.6 \%)$ with swelling over the back, in $5(6.9 \%)$ of patient we observed a hairy patch and dermal sinus each while 28 (38.8\%) patient had neurological deficit. Similar results were observed in a study done by Venkatesh in India in 2016 showing $72 \%$ of patients presented with a visible sac over the back and a minority presented with dermal sinus and neurological deficit. ${ }^{17}$

In our study the most common type of spinal dysraphism was myelomeningocele 45 (62.5\%), followed by lipomyelomeningocele 12 (16.6\%), dermal sinus $4(5.5 \%)$, Klippel - Feil syndrome or blocked vertebrae $2(2.7 \%)$, tethered cord syndrome 6 $(8.3 \%)$ and split cord malformation seen in $3(4.16 \%)$. Myelomeningocele are mostly associated with hydrocephalus either before or after surgical repair which later need a CSF diversion procedure. A similar study was done by Pornswan et al in 2005 and Ahmed et al in 2010. ${ }^{18,19}$

Spinal dysraphism commonly occur at lumbosacral area, many study reported lumbosacral area as common site, however Asindi and Al-Sehri had conducted a contradictory report showing dorsolumbar area the most common site. ${ }^{20}$

Postoperative course of patients with spinal dysraphism was found to be uneventful in $56(77.7 \%)$, wound infection was seen in $11(15.2 \%)$, deterioration of neurological status in $3(4.16 \%)$ and re exploration was done in $2(2.77 \%)$ of cases. A similar study was done by Galhom et al showing a dramatic improvement in symptoms with only a minority of patients experience wound infection and worsening of neuro deficit. ${ }^{21-23}$

\section{CONCLUSION}

Spinal dysraphism is not an uncommon condition in our local population its clinical presentation and features are in line with internationally reported literature. Our population is least aware of the adverse neurological outcomes of the condition and face difficulties to access the adequate healthcare for spinal dysraphism.

\section{REFERENCES}

1. Nafees M, Akram MH. MR image spectrum of spinal dysraphism in a milirary Hospital. Journal of Army Medical Crop. 2012; 1 (3): 74-78.

2. Dawoud MF. Role of MRI in diagnosis of spinal congenital anomalies radiology and neurosurgery. Tanta Medical Sciences Journal, 2007; 2 (1): 182-193.

3. Kumar R, Singh SN. Spinal dysraphism: Trends in Northern India Journal, 2003; 38 (3): 133-145.

4. Shin M. Birth defects epidemiology and surveillance. Prevelance of spina bifida among children and adolescents in 10 regions in the United States. Journal of Pediatrics, 2010; 126 (2): 174-9.

5. Rufener S, Ibrahim M, Parmar HA. Imaging of congenital spine and spinal cord malformations. Neuroimaging Clin N Am. 2011; 21 (3): 59-76.

6. Smith JL. Management of neural tube defects, hydrocephalus, refractory epilepsy and central nervous system infections. Pediatric Surgery, 2012; 12 (1): 1673-97.

7. Steinbok P. Dysraphic lesion of cervical spinal cord. Neurosurg Clin N Am. 1995; 69 (2): 367-76. 
8. Boyd PA, Wallesley DG, DeWalle HE, Tenconi R, Gracica-Minaur S, Zandwijkern GR, et al. Evaluation of the prenatal diagnosis of neural tube defect by fetal ultrasonographic examination in different centre across Europe. Journal of Medical Screen, 2000; 7 (1): 169-74.

9. Dias MS, Partington M. Embryology of myelomeningocele and anencephaly. Neurosurg Focus, 2004; 16 (2): 174-79.

10. Hashim AS, Ahmed S, Jooma R. Management of meyelomeningocele. Journal of Surgery (International), 2008; 13 (1): 7-11.

11. Johnson MP, Grades M, Rintoul N, Pasquariello P, Melchionni J, Sutton N, et al. Maternal-fetal surgery for myelomeningocele: Neurodevelopment outcome at 2 years of age. Am Journal Obstret Gynecol. 2006; 194 (3): 1145-50.

12. Kumari MV, Suprya P, Aemjal SC, et al. Role of MRI in evaluation of suspected spinal dysraphism. J. Evolution Med. Dent. Sci. 2016; 5 (17): 879-884.

13. Copp AJ, Stanier P, Greene NDE. Neural tube defectrecent advances unsolved question and controversies. Lancet Neurology, 2013; 12 (8): 799-810.

14. Nishtar T, Elahi A, Iqbal N. To determine the frequency of accuracy of MRI in diagnosis of rare disorder of spinal dysraphism. J Med Sci. 2011; 19 (4): 195-199.
15. Ackermal LL, Menezes AH. Spinal congenital dermal sinuss: A 30 years experience. Journal of Pediatric, 2003; 112 (5): 641-647.

16. Kumar R, Singh SN. Spinal dysraphism: Trends in northern India Journal, 2003; 38 (3): 133-145.

17. Venkatesh KL. Study of clinical profile and associated anomalies and surgical outcome of spina bifida. Int Surg J. 2017; 4: 141-5.

18. Pornswan Wasant, Achara Sathienkijkanchai. Neural tube defects at Siriraj Hospital Bangkok-10years review. J Med Assoc Thai. 2005; 88 (8): 115-119.

19. Ahmed M, Limbu CP, Mughal SH. Pattern of presentation of spinal dysraphism. Pak J of Neurol Surg. 2010; 14 (2): 127-130.

20. Asindi Asindi, Ameer AL. Neural tube defect in the Asir region of Saudi Arabia. Annals of Saudi Mediciene, 2001; 21 (1): 169-74.

21. Galhom AE, Deeb WA, Osama A. Early clinical characteristics and surgical outcome in 10 children with occult spinal dysraphism. Egypt J Neurol Psychiat Neurosurg. 2013; 50 (2): 127-34.

22. Erfani MA, Ganjavian MS, Ameri E, Namazi H, Sooloki S, Samini M. Orthopedic lesion in tethered cord syndrome: the importance of early diagnosis and treatment on patient outcome.Arch Bone Joint Surg. 2014; 292: 53-57.

\section{Additional Information}

Disclosures: Authors report no conflict of interest.

Ethical Review Board Approval: The study was conformed to the ethical review board requirements.

Human Subjects: Consent was obtained by all patients/participants in this study.

Conflicts of Interest:

In compliance with the ICMJE uniform disclosure form, all authors declare the following:

Financial Relationships: All authors have declared that they have no financial relationships at present or within the previous three years with any organizations that might have an interest in the submitted work.

Other Relationships: All authors have declared that there are no other relationships or activities that could appear to have influenced the submitted work.

Address for Correspondence:

Muhammad Nawaz Khan

Neurosurgery Department

Hayatabad Medical Complex/MTI. Peshawar

Email ID:dr.nawaz2009@yahoo.com 


\section{AUTHORS CONTRIBUTIONS}

\begin{tabular}{|l|l|l|}
\hline Sr.\# & Author's Full Name & Intellectual Contribution to Paper in Terms of: \\
\hline 1. & Sohail Amir & Study design and methodology. \\
\hline 2. & M. Nawaz Khan & Paper writing, referencing, data calculations and Correspondence \\
\hline 3. & M. Imran & Data collection and calculations \\
\hline 4. & Ayaz Afridi & Analysis of data and interpretation of results etc. \\
\hline 5. & M. Atif & Literature review and manuscript writing \\
\hline 6. & Mushtaq & Analysis of data and quality insurer \\
\hline 7. & Shahid Ayub & Proof reading \\
\hline
\end{tabular}

Date of Submission: 11-04-2020

Date of Revision: 27-8-2020

Date of Online Publishing: 25-09-2020

Date of Print: 30-09-2020 